\title{
Case Report of a Neonate Born to a Mother with Severe SARS-CoV-2 Infection under ECMO
}

\section{Caso Clínico de um Recém-Nascido de Mãe com Infeção Grave por SARS-CoV-2 sob ECMO}

\author{
Ana Sofia VILARDOURO $\varpi^{1}$, Mafalda CASTELÃO ${ }^{1}$, Paula COSTA ${ }^{2,3}$, Margarida ABRANTES ${ }^{2,3}$ \\ Acta Med Port 2022 Apr;35(4):298-300 - https://doi.org/10.20344/amp.16673
}

\begin{abstract}
Neonatal SARS-CoV-2 infections are rare and although there is some evidence of vertical transmission, most newborns show no clinical signs or present with only mild clinical symptoms. Fetal survival is reported around $70 \%$ in mothers submitted to extracorporeal membrane oxygenation. We present a case of a male newborn born at 29 weeks from a mother under extracorporeal membrane oxygenation due to SARS-CoV-2 infection. There was no evidence of vertical transmission, polymerase chain reaction testing of nasopharyngeal/throat swab and polymerase chain reaction testing of blood sample for SARS-CoV-2 were both negative. On day 2, he developed signs of osteomyelitis of the distal femur extremity, which resolved after six weeks of antibiotic therapy, with no other significant events during admission. This case report depicts the favorable outcome of a live infant born to a mother with severe SARS-CoV-2 infection under extracorporeal membrane oxygenation.
\end{abstract}

Keywords: COVID-19; Extracorporeal Membrane Oxygenation; Infant, Newborn; Osteomyelitis; SARS-CoV-2

\section{RESUMO}

A infeção neonatal por SARS-CoV-2 é rara e apesar de existir alguma evidência da possibilidade de transmissão vertical, a maioria dos recém-nascidos não manifesta quaisquer sinais clínicos ou apresenta apenas sintomas ligeiros. A sobrevivência fetal é de aproximadamente $70 \%$ para grávidas que tenham necessitado de oxigenação por membrana extracorporal. Apresentamos um caso de um recém-nascido do sexo masculino, nascido às 29 semanas de idade gestacional de uma mãe sob oxigenação por membrana extracorporal, devido a infeção por SARS-CoV-2. Não se verificou evidência de transmissão vertical, e a reação em cadeia da polimerase de amostras nasofaríngeas e sanguíneas foi negativa. No segundo dia de vida desenvolveu sinais compatíveis com osteomielite da extremidade distal do fémur, resolvidos após seis semanas de antibioticoterapia, sem outras intercorrências relevantes durante a admissão. Este caso revela uma evolução clínica favorável de um recém-nascido, filho de mãe com infeção grave por SARS-CoV-2 sob oxigenação por membrana extracorporal.

Palavras-chave: COVID-19; Osteomielite; Oxigenação por Membrana Extracorpórea; Recém-Nascido; SARS-CoV-2

\section{INTRODUCTION}

An outbreak of coronavirus disease in December 2019 (COVID-19) caused by severe acute respiratory syndrome coronavirus-2 (SARS-CoV-2) occurred in Wuhan, China, leading to a worldwide pandemic. ${ }^{1,2}$ Neonatal SARS-CoV-2 infections are rare and although there is evidence of vertical transmission, most newborns show no clinical signs. ${ }^{1,3}$ The majority of pregnant women with COVID-19 experience mild to moderate symptoms and only a few have severe disease. ${ }^{4}$ Studies concerning the use of ECMO in COVID-19 describe mortality rates ranging from $15 \%-50 \%$. However, data on ECMO during pregnancy is very limited. ${ }^{5}$ Additionally, pregnant women and patients under extracorporeal membrane oxygenation (ECMO) are at higher risk of infection/sepsis. ${ }^{6,7}$ The decision when to deliver the neonate in a pregnant woman under ECMO, requires multidisciplinary discussion and should be made on an individual basis. ${ }^{6}$ Fetal survival after maternal ECMO, is reported to be approximately $70 \%{ }^{5}$ The most commonly fetal complication is preterm delivery and less frequently respiratory distress, low birth weight, disseminated intravascular coagulation, asphyxia and death. ${ }^{3,7}$
This case describes the clinical course and outcomes of a live infant born to a mother with severe SARS-CoV-2 infection under ECMO.

\section{CASE REPORT}

Male newborn, birth at 29+5 weeks from a 31-year-old gravida 1, para 1, via cesarean-section. His parents were non-consanguineous and had African ancestry.

At 28 weeks of gestation, the mother was admitted in an intensive care unit, due to severe SARS-CoV-2 infection and required invasive ventilation and venovenous-ECMO. She was diagnosed with Serratia marcescens sepsis and treated with meropenem. Antenatal steroids for lung maturation were administered. Obstetric ultrasonography showed fetal blood flow redistribution and the pregnancy was interrupted at $29+5$ weeks after severe preeclampsia diagnosis.

The baby weighed $1044 \mathrm{~g}$ (appropriate for gestational age), and invasive endotracheal intubation was performed in the first minute due to respiratory failure, and therapeutic surfactant was administered. Apgar's scores were 8 at 1

1. Department of Pediatrics. Hospital Santa Maria. Centro Hospitalar Universitário Lisboa Norte. Lisbon. Portugal.

2. Neonatal Intensive Care Unit. Department of Pediatrics. Hospital Santa Maria. Centro Hospitalar Universitário Lisboa Norte. Lisbon. Portugal.

3. Faculdade de Medicina. Universidade de Lisboa. Lisbon. Portugal.

$\triangle$ Autor correspondente: Ana Sofia Vilardouro. asvilardouro@gmail.com

Recebido/Received: 16/06/2021 - Aceite/Accepted: 16/12/2021 - Publicado Online/Published Online: 28/01/2022 - Publicado/Published: 01/04/2022 Copyright @ Ordem dos Médicos 2022 
and 5 minutes. At the Neonatal Intensive Care Unit (NICU) he required up to $80 \%$ oxygen; mild ground glass opacities were present on chest X-ray. Intravenous meropenem and gentamicin were started considering his mother's sepsis and Serratia's susceptibility testing. Inflammatory parameters, complete blood cell count and coagulation tests were normal. On day 2, polymerase chain reaction (PCR) testing of nasopharyngeal/throat swab and PCR testing of blood sample were negative for SARS-CoV-2.

On day 2, a mild swelling on the left thigh and knee was observed. Radiograph of the lower left limb showed irregularities of the femur distal extremity. An ultrasound (US) revealed increased volume and mild diffuse heterogeneity of the left thigh muscles, and absent intra-articular effusion. A diagnosis of osteomyelitis was assumed and antibiotic therapy was switched to meropenem and vancomycin. On day 10 a subperiosteal abscess of the distal third of the femur was diagnosed and drained. He completed six weeks of antibiotics with improvement of swelling and limb mobility. Inflammatory parameters, blood and pus cultures were negative, such as a PCR testing for Serratia spp ribosomal DNA in blood sample.

Invasive ventilation was required on day 1 , with no need for supplemental oxygen since day 47. Cerebral US on day 1 showed moderate parieto-occipital periventricular echogenicity, which was present until 31 weeks postmenstrual age (PMA), and compatible with leukomalacia grade I. Brainstem auditory evoked potentials were normal and the ophthalmological observation excluded retinopathy of prematurity. The patient was discharged at 37 weeks PMA with adequate weight and height progression. One month after discharge he was healthy and thriving well, although a shortening of the left lower extremity and femur varus deviation was noted.

\section{DISCUSSION}

The SARS-CoV-2 pandemic has put our healthcare systems under enormous pressure, leading to an unprecedented need for rapid adaptation and the unique challenge of having very limited scientific knowledge and clinical experience available. This case is a positive example of uncharted territory, where the combined factors caused by the complicated course of COVID-19, ECMO requirement, maternal septic shock, preeclampsia and prematurity, could further increase the potential for neonatal adverse outcomes.

The negative tests for COVID-19 in the newborn are consistent with published data indicating extremely low rates of vertical transmission. ${ }^{1}$ The newborn had no clinical evidence for neonatal SARS-CoV-2 infection; the need for transitory ventilation and findings of mild glass opacities on chest X-ray were related with prematurity.

While fetal mortality during maternal ECMO is reported to be as high as $30 \%$, delivery on ECMO can be performed safely, if supported by multidisciplinary teams. The risk of bleeding and intraventricular hemorrhage seems to be closely associated with prematurity and low birth weight, rather than with ECMO anticoagulation. ${ }^{7}$ In our case study, only transitory periventricular and parieto-occipital echogenicity was observed on serial cerebral US, and there was no evidence of bleeding or thrombotic complications. Low birth weight is another commonly reported fetal complication of delivery on ECMO. ${ }^{7}$ This neonate was born with very low birth weight, albeit appropriate for his gestational age. This complication could be associated not only with prematurity and ECMO, but with prolonged maternal usage of high dose systemic corticosteroids and the impact of severe maternal debilitating illness on normal fetal growth. ${ }^{7}$

Despite severe maternal SARS-CoV-2 infection, the newborn required NICU admission due to prematurity and its common problems. However, a rare infectious complication developed within the first 48 hours, possibly associated with maternal sepsis. Although no causative agent was identified, the severe maternal sepsis at the time of delivery, which can increase the risk of early neonatal infection, and the improvement after switching to broad spectrum antibiotics, raises suspicion of Serratia spp femur osteomyelitis. ${ }^{9}$ Although no acute complications were observed and the local infection resolved completely, long-term complications, such as limb growth disturbances and bone deformity, warrant close follow-up and early intervention. This preterm will have longitudinal multidisciplinary assessments in neonatology, neurodevelopmental, orthopedics, ophthalmology and otorhinolaryngology appointments. He is currently engaging in a rehabilitation plan and waiting for a cerebral magnetic resonance imaging scan.

Finally, we emphasize the importance of multidisciplinary discussion on the birth planning of a severely affected pregnant women with COVID-19. Postponing delivery allowed the birth of a more mature baby, a key to success and to discharge home a healthy mother and son.

\section{AUTHORS CONTRIBUTION}

ASV: Literature research, design of the work, data acquisition, analysis and interpretation, draft of the paper, critical review of the manuscript.

MC: Literature research, design of the work, data analysis and interpretation, draft of the paper, critical review of the manuscript.

PC, MA: Literature research, data analysis and interpretation, critical review of the manuscript.

\section{PROTECTION OF HUMANS AND ANIMALS}

The authors declare that the procedures were followed according to the regulations established by the Clinical Research and Ethics Committee and to the Helsinki Declaration of the World Medical Association updated in 2013.

\section{DATA CONFIDENTIALITY}

The authors declare having followed the protocols in use at their working center regarding patients' data publication.

\section{PATIENT CONSENT}

Obtained. 


\section{COMPETING INTERESTS}

The authors have declared that no competing interests exist.

\section{REFERENCES}

1. Neef V, Buxmann H, Rabenau HF, Zacharowski K, Raimann FJ. Characterization of neonates born to mothers with SARS-CoV-2 infection: review and meta-analysis. Pediatr Neonatol. 2021;62:11-20.

2. Vivanti AJ, Vauloup-Fellous C, Prevot S, Zupan V, Suffee C, Cao JD, et al. Transplacental transmission of SARS-CoV-2 infection. Nat Commun. 2020;11:1-7.

3. Zimmermann P, Curtis N. COVID-19 in children, pregnancy and neonates: a review of epidemiologic and clinical features. Pediatr Infect Dis J. 2020;39:469-77.

4. Krishnamurthy G, Sahni R, Leone T, Kim F, Brooks MC, VillarazaMorales S, et al. Care of the COVID-19 exposed complex newborn infant. Semin Perinatol. 2020;44:151282.

5. Sebastian NA, Spence AR, Bouhadoun S, Abenhaim HA. Extracorporeal membrane oxygenation in pregnant and postpartum patients: a

\section{FUNDING SOURCES}

This research received no specific grant from any funding agency in the public, commercial, or not-for-profit sector

systematic review. J Matern Neonatal Med. 2020;0:1-11.

6. Biffi S, Di Bella S, Scaravilli V, Peri AM, Grasselli G, Alagna L, et al. Infections during extracorporeal membrane oxygenation: epidemiology, risk factors, pathogenesis and prevention. Int J Antimicrob Agents. 2017;50:9-16.

7. Douglass KM, Strobel KM, Richley M, Mok T, St Maurice A, Fajardo V, et al. Maternal-neonatal dyad outcomes of maternal COVID-19 requiring extracorporeal membrane support: a case series. Am J Perinatol. 2021;38:82-7.

8. Naoum EE, Chalupka A, Haft J, MacEachern M, Vandeven CJ, Easter $\mathrm{SR}$, et al. Extracorporeal life support in pregnancy: a systematic review. J Am Heart Assoc. 2020;9:e016072.

9. Chen $Y$, Peng H, Wang L, Zhao Y, Zeng L, Gao H, et al. Infants born to mothers with a new coronavirus (COVID-19). Front Pediatr. 2020;8:104. 